\title{
Recent changes in sediment redistribution in the upper parts of the fluvial system of European Russia: regional aspects
}

\author{
O.P. YERMOLAEV ${ }^{1}$, V.N. GOLOSOV ${ }^{1,2}$, M.V. KUMANI ${ }^{3}$, L. F. LITVIN ${ }^{2}$, \\ I.I. RYSIN ${ }^{4}$ \& A.P. DVINSKIKH ${ }^{1}$ \\ 1 Kazan Federal University, Kremlevskayast., 18, Kazan, 420008, Russia \\ oyermol@gmail.com \\ 2 Lomonosov Moscow State University, Leninskie Gory, 1, GSP-1, 119991, Moscow, Russia \\ 3 Kursk State University, Radischeva st.,33, 305000, Kursk, Russia \\ 4 Udmurt State University, Universitetskayast., 1, 426034, Izhevsk, Udmurt Republik, Russia
}

\begin{abstract}
Quantitative assessments of soil loss from cultivated land and sediment redistribution along pathways from cultivated fields to river channels have been undertaken using a range of different methods and techniques, including erosion models, detailed studies of sediment redistribution in representative catchments, monitoring of gully head retreat and evaluation of sediment deposition in ponds and small reservoirs. Most of the sediment eroded from arable land is deposited between the lower portions of the cultivated slopes and the river channels. Less than $15 \%$ of the eroded sediment is delivered to the river channels. Sediment redistribution rates in the upper parts of the fluvial system have declined during the last 25 years in both the western and eastern parts of the Russian Plain, because of a major reduction of surface runoff during snowmelt and a reduction of the area of arable land in some parts of the study area.
\end{abstract}

Key words soil erosion; sediment deposition; gully head retreat; sediment budget; land-use change; climate change; Russian Plain

\section{INTRODUCTION}

During the past decade, increasing attention has been directed to quantification of sediment transfer through fluvial systems because of improvements in both the available techniques and modelling strategies (Brown et al., 2009). However, such attention has also been promoted by interest in the impact of climate and land-use change, which can exert an important influence on the fluvial system in different landscape zones (Nearing et al., 2004; Mullan, 2013). Quantitative evaluation of recent trends in sediment redistribution rates can be used to validate different models of landscape change under anthropogenic pressure and climate change (Schoorl et al., 2002; Van de Wiel et al., 2007).

European Russia largely comprises a vast plain that can be divided into two parts by a line connecting Bryansk-Moscow-Kazan-Ufa. These two parts are characterized by different patterns of sediment redistribution within the upper parts of the fluvial system. To the north of this line, the land is mostly forested with a relatively low proportion of cultivated land. To the south, the proportion of arable land increases considerably (up to $70-75 \%$ of the total area). In the northern part of European Russia, sediment transport in the fluvial system is generally dominated by sediment mobilised from the river channels, whereas in the southern half of European Russia soil loss from cultivated fields represents the primary sediment source. The southern half of the Russian Plain has the highest proportion of cultivated land and a relatively recent history of intensive agriculture, comparable with that of the Great Plains of the USA (Ramankutty \& Foley, 1999). The zone with the maximum erosion rates gradually shifted during the 17th-19th centuries from the taiga to the broad-leaved forest and then to the forest-steppe, in response to the expansion of the cultivated area (Sidorchuk \& Golosov, 2003). Soil erosion rates reached a maximum during the period extending from the second half of the 19th century to around 1985, in the forest-steppe zone of the Russian Plain. Significant changes in sediment redistribution rates have since occurred in the agricultural zone of European Russia, as a result of both climate change and a reduction of the cultivated area during last two to three decades (Golosov et al., 2013). The aim of this paper is to provide a quantitative assessment of recent trends in the magnitude of sediment redistribution rates in the upper part of the fluvial system in different parts of the Russian Plain, located primarily in the forest-steppe zone within the Srednerusskaya Upland and the Srednee Povolzhie regions (Fig. 1). 


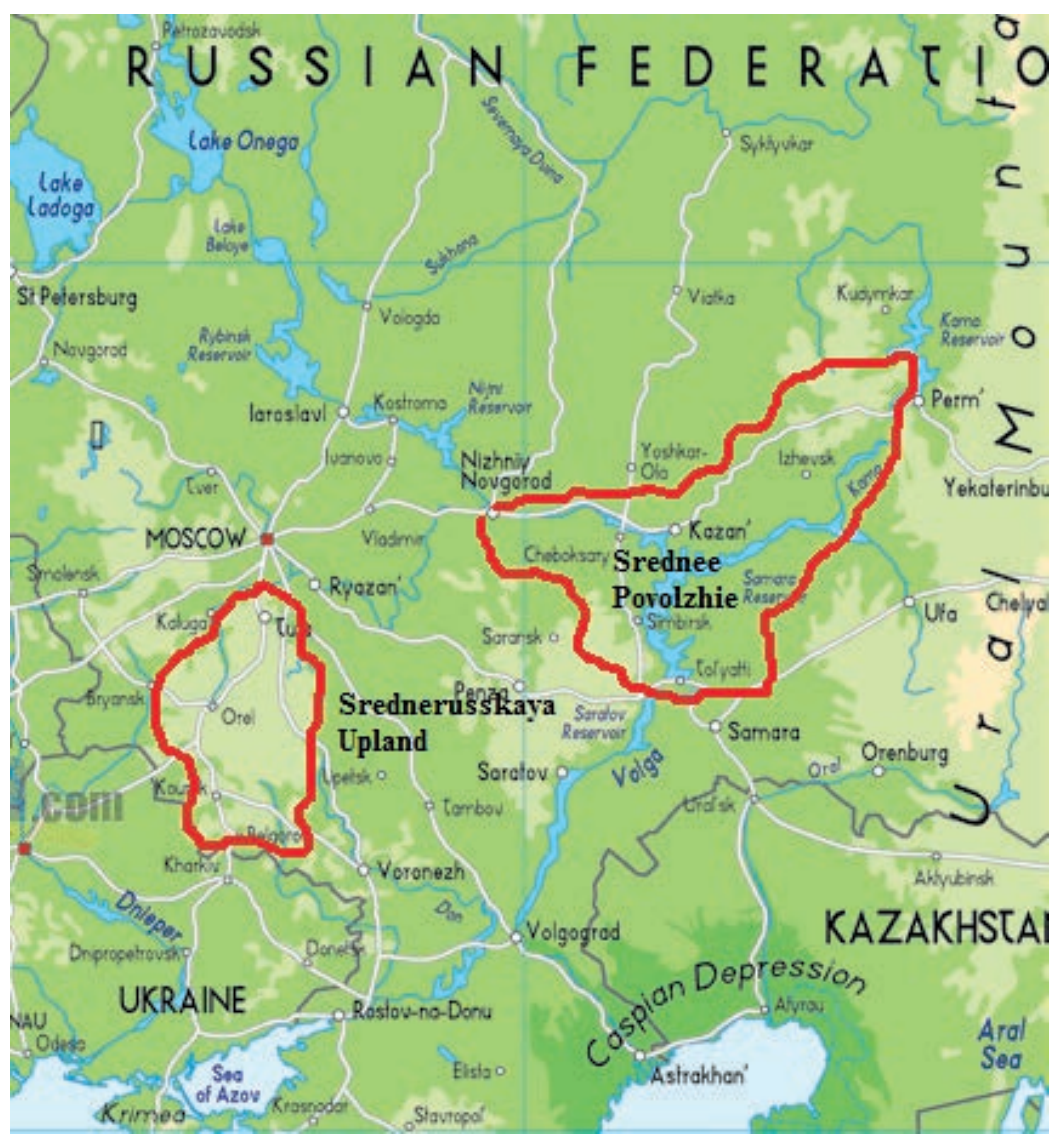

Fig. 1 Location of the Srednerusskaya Upland and Srednee Povolzhie on the Russian Plain.

\section{FACTORS AFFECTING CHANGES IN SEDIMENT REDISTRIBUTION RATES}

There are two main groups of factors responsible for changes in sediment redistribution within the fluvial system in different parts of the Russian Plain, namely fluctuations in climate and land-use change.

Climate fluctuations can exert opposing influences on sediment redistribution. The trend of increasing winter temperature coupled with a decrease in the depth of frozen soil during the last two decades (Perevedentsev et al., 2007) has resulted in a sharp reduction in surface runoff from cultivated slopes during snowmelt. Monitoring of spring snowmelt runoff on cultivated slopes within the Novisil experimental station (Orel region) has demonstrated a marked decrease in the runoff coefficient during the last 12 years (Petelko et al., 2007). A similar trend was detected by monitoring undertaken in the upper part of the Lebedin catchment (the Gracheva Loschina experimental catchment) during the period 1986-2002 (Kumani, 2003).This reduction in spring snowmelt runoff has resulted in a major reduction in associated soil loss, which has resulted in a significant change in the overall sediment budget. In contrast, the mean intensity of high magnitude precipitation events (exceeding the 95th percentile and contributing $25-40 \%$ to the total) occurring during the warmer months has increased by 6-8\% per decade (Zolina et al., 2010). As a result it is likely that surface runoff from cultivated slopes has increased during this period of the year in the Russian Plain. This is confirmed by the results of detailed analyses of rainfall records for the Srednerusskaya Upland (Golosov et al., 2010) and Srednee Povolzhie (Kanatieva et al., 2010). The annual USLE erosivity index has increased by $5-6 \%$ in the Srednerusskaya Upland and by $2-3 \%$ in the Srednee Povolzhie region. However most of the sediment eroded during rainstorms is deposited close to the arable fields because of the high turbidity of the surface runoff. As a result of these different trends, there has been an overall decrease in sediment redistribution rates across the Russian Plain in recent years as a result of climate fluctuations. Land-use changes 
during the last two decades were slightly different in the two regions investigated. In the case of the Srednerusskaya Upland, the maximum increase in the area of abandoned land occurred in the northern part, where in 2006 the area of abandoned land represented $10-12 \%$ of the total area of cultivated land in 1980. Elsewhere in this region, the equivalent value is $6.6 \%$, although there is clear evidence of a recent increase in the area of cultivated land during the period 2006-2014. Over the same time period (1980-2006), the area of abandoned land in Srednee Povolzhie reached 10\% (Litvin et al, 2010) and has continued to increase during the period 2006-2014. More detailed investigations undertaken in the western part of Srednee Povolzhie have demonstrated that most abandoned land is located on relatively steep (6-7\%) slopes (Kanatieva et al., 2010). Such a situation is typical for the other parts of the region. It is therefore more likely that land-use change has caused a reduction in soil loss from cultivated land in the Srednee Povolzhie region.

\section{AN ASSESSMENT OF CHANGES IN SEDIMENT REDISTRIBUTION FOR A TYPICAL SMALL CATCHMENT}

An assessment of changes in sediment redistribution rates was undertaken for the $15.2 \mathrm{~km}^{2}$ Lebedin catchment, which is a typical Hortonian 3rd order catchment located within the River Vorobzha basin, in the south-western part of the Srednerusskaya Upland. An earth dam was constructed at the outlet of the catchment in 1956. This has permitted a detailed sediment budget to be established for the catchment. An integrated approach, involving the use of erosion models, dating of sediment deposits using ${ }^{137} \mathrm{Cs}$ and large-scale geomorphic mapping, was used to quantify soil loss/gain on the cultivated hillslopes and in different order catchments over several time periods since the middle of the 20th century. In addition, meteorological data and detailed information on land use and crop rotation changes were assembled for the study area for a 60 year period.

The resulting estimates of sediment delivery into the main valley of the Lebedin catchment were compared with sedimentation rates and volumes derived from analysis of the ${ }^{137} \mathrm{Cs}$-based valley bottom sediment microstratigraphy, including the dry reservoir infill. Gross erosion rates for arable hillslopes during the periods 1956-1964, 1964-1986 and 1986-2008, calculated using a USLE-based model and information on the known extent of the cultivated areas and the crop rotations, were estimated to be $8.6,10.6$ and $6.8 \mathrm{t} \mathrm{ha}^{-1}$ year $^{-1}$, respectively (Table 1). In addition to sediment deposition in the valley bottoms, other sediment sinks exist (Table 2).

Table 1 Mean annual erosion rates and total soil losses from cultivated slopes in the Lebedin catchment for three time intervals covering the period after dam construction at the catchment outlet.

\begin{tabular}{lcc}
\hline Time interval (years) & Mean annual erosion rate $\left(\mathrm{t} \mathrm{ha}^{-1}\right.$ year $\left.^{-1}\right)$ & Total soil loss $(\mathrm{t})$ \\
\hline 1956-1964 & 8.5 & 83912 \\
$1964-1986$ & 10.6 & 287769 \\
1986-2008 & 6.8 & 191848 \\
Mean for period 1956-2008 & 8.6 & 563529 \\
\hline
\end{tabular}

Based on direct measurements after snowmelt and storm runoff events, deposition of mobilized sediment within the cultivated fields was generally found to vary within a range of $2-25 \%$ of the gross soil loss from the respective fields. Conveyance losses of this magnitude have also been indicated by detailed studies of gross and net erosion rates on the catchment slopes using the ${ }^{137} \mathrm{Cs}$ technique (Golosov et al., 2011). Data obtained after extreme erosion events and during snowmelt periods showed that about $2-7 \%$ of the sediment mobilized from the cultivated land was deposited within the grassed valley sides (Belyaev et al., 2008). Sediment deposition in the uncultivated parts of slope hollows (most of which represents infilled formerly active valley side gullies) was estimated based on direct measurements of total sediment volumes stored in a representative selection of hollows in the catchment and extrapolation of the results to all the uncultivated hollows on the valley sides of the Lebedin catchment. By combining all the above data and comparing the results with the USLE-based soil loss calculations, it was concluded that the latter overestimated total soil loss from the cultivated slopes of the Lebedin catchment by about $11 \%$ (Table 2 ). 
Table 2 Percentage of the mobilised sediment deposited in different depositional zones of the Lebedin catchment during the period 1956-2008.

\begin{tabular}{|c|c|c|}
\hline \multirow[t]{2}{*}{ Deposition zone } & \multicolumn{2}{|c|}{$\%$ of gross soil loss deposited in given zone } \\
\hline & Range (based on observations) & Mean value \\
\hline Within arable lands & $2-25$ & 10 \\
\hline Near the lower edge of cultivated fields & $5-30$ & 8 \\
\hline Valley sides & $2-7$ & 4 \\
\hline $\begin{array}{l}\text { Uncultivated part of hollows (former valley side } \\
\text { gullies) }\end{array}$ & $4-10$ & 6 \\
\hline Bottom of valleys including ponds and reservoirs & - & 51 \\
\hline Sediment passing the reservoir dam & $5-15$ & 10 \\
\hline Residual & - & 11 \\
\hline
\end{tabular}

It can be suggested that the volume of sediment deposited within the main reservoir at the catchment outlet during the different periods was proportional to the volume of sediment exported from the Lebedin catchment during those periods. In this respect, it is noteworthy that before 1986 about $12 \%$ of the total soil loss or a total equivalent to about $21 \%$ of the total deposition in the valley bottoms, reached the catchment outlet. After 1986 the percentage of sediment reaching the Lebedin catchment outlet decreased more than threefold, mainly as a result of reduced surface runoff and associated erosion during the spring snowmelt period. Consequently, it can be tentatively suggested that during the last two decades, the volume of sediment delivered into the River Vorobzha valley from its main tributary catchments fell by about one third.

Evaluation of sediment volumes deposited in ponds and reservoirs within the Srednerusskaya Upland provides information on the mean annual sediment yield from catchments of different size (Table 3). It was found that for the ponds and reservoirs with catchment areas of $10-50 \mathrm{~km}^{2}$, only about $14 \%$ of the sediment eroded from the fields was delivered to the pond or reservoir. This is in good agreement with the findings of the detailed study of sediment redistribution in the Lebedin catchment reported above. It can therefore be suggested that the trend of decreasing sediment transport from cultivated fields to the river channels during the last two decades noted above reflects the considerable reduction of surface runoff and associated erosion rates during the snowmelt period. This conclusion is also confirmed by information on changing overbank sedimentation rates within small and medium sized river basins within the Srednerusskaya Upland (Golosov et al., 2010). It was found that sedimentation rates decreased by a factor of 2.5-3 when the period 1986-2009 was compared with the period 1964-1986.

Table 3 Specific sediment yields (SSY) determined from the volume of sediment deposited in ponds and reservoirs within the Srednerusskaya Upland with different catchment areas.

\begin{tabular}{|c|c|c|c|c|c|c|c|c|}
\hline \multirow[t]{2}{*}{ Sediment sink } & \multirow{2}{*}{$\begin{array}{l}\text { Catch- } \\
\text { ment area } \\
\left(\mathrm{km}^{2}\right)\end{array}$} & \multirow{2}{*}{$\begin{array}{l}\text { Number } \\
\text { ponds or } \\
\text { reservoirs }\end{array}$} & \multirow{2}{*}{$\begin{array}{l}\text { Mean catch- } \\
\text { ment area } \\
\left(\mathrm{km}^{2}\right)\end{array}$} & \multicolumn{5}{|c|}{ Specific sediment yield $\left(\mathrm{t} \cdot \mathrm{km}^{-2} \cdot\right.$ year $\left.^{-1}\right)$} \\
\hline & & & & Mean & Max & Min & Std dev. & $\mathrm{C}_{\mathrm{v}}$ \\
\hline $\begin{array}{l}\text { Small in-field } \\
\text { ponds }\end{array}$ & $<0.25$ & 10 & 0.12 & 686 & 2230 & 320 & 590 & $86 \%$ \\
\hline Small reservoirs & $0.25-10$ & 11 & 4.5 & 133 & 309 & 37 & 96 & $73 \%$ \\
\hline $\begin{array}{l}\text { Medium } \\
\text { reservoirs }\end{array}$ & $10-50$ & 28 & 32 & 102 & 194 & 5 & 53 & $52 \%$ \\
\hline Large reservoirs & $50-100$ & 17 & 73 & 87 & 144 & 24 & 37 & $44 \%$ \\
\hline
\end{tabular}

Sediment redistribution within the fluvial system of the Srednerusskaya Upland is very similar to that in some other regions of Europe (Verstraeten \& Poesen, 2001). It is characterised by the deposition of a high proportion of the sediment eroded from cultivated land in various different sediment sinks prior to its reaching the river channel (Fig. 2).

The Srednee Povolzhie region is also characterized by considerable variation of rates of soil loss from cultivated land, because it includes both upland and lowland. The mean annual soil loss during spring snowmelt estimated for the region using an erosion model is $0.46 \mathrm{t} \mathrm{ha}^{-1} \mathrm{year}^{-1}$. This is 
one order of magnitude less than the equivalent rainfall erosion rate of $5.56 \mathrm{t} \mathrm{ha}^{-1}$ year-1 (Yermolaev \& Maltsev, 2008). Maximum total soil loss is associated with the western part of the region within the Privolzhskaya Upland and the southeastern part, the Bugulmino-Belebeevskaya Upland. However, soil type exerts an important influence on erosion rates within the region. The results of detailed field surveys of soil loss associated with the entire period of intensive cultivation for different soil types indicate that maximum erosion rates occurred areas with different types of grey forest soils (Yermolaev, 2002, 2013, 2014). A study of sediment deposition in ponds and small reservoirs with catchment areas up to $50 \mathrm{~km}^{2}$ was undertaken in the Srednee Povolzhie region in the mid 1980s. Most of the impoundments were constructed at the beginning of the 1970s, and so the mean annual values of specific sediment yield produced by this survey data are representative of the period 1970-1988. The study indicated a mean value of SSY of $650 \mathrm{t}$ $\mathrm{km}^{-2}$ year ${ }^{-1}$ and a range of $460-850 \mathrm{t} \mathrm{km}^{-2}$ year-1. The range of values documented reflected a number of factors, including catchment size, the proportion of land under cultivation, the gradient of the cultivated slopes and the soil type. In general, these values fall within the same range as the estimates of current total soil loss from cultivated land in the region provided by erosion models (mean $6.12 \mathrm{t} \mathrm{ha}^{-1}$ year $^{-1}$ ). However it is necessary to recognise that the values of SSY based on the volume of sediment deposited in ponds and reservoirs represent values of net soil loss from the catchments. It is likely that the gross soil loss from the cultivated fields was at least 2-3 times higher (see Fig. 2 for the Srednerusskaya Upland). Hence it can be suggested that rates of gross

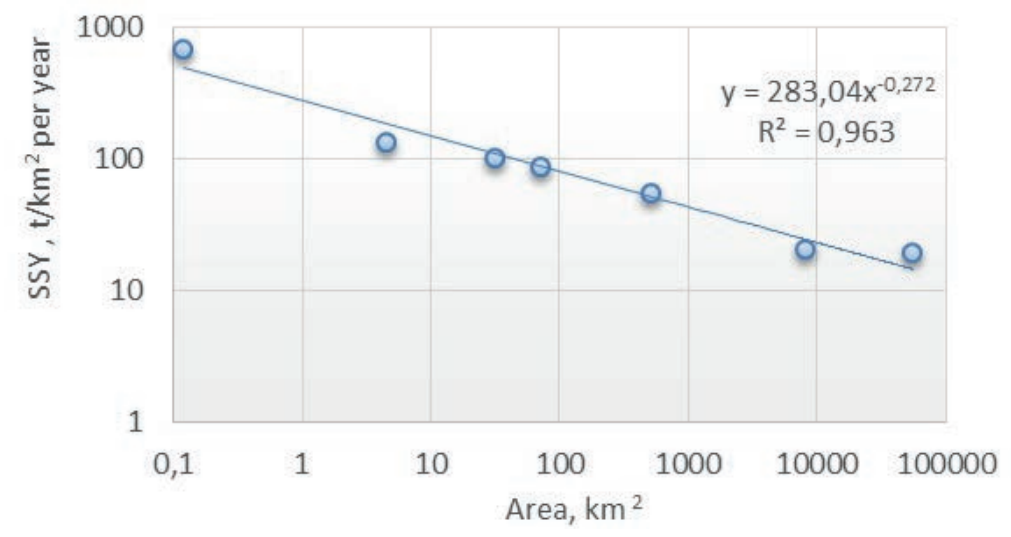

Fig. 2 The relationship between specific sediment yield (SSY) and catchment area for the Srednerusskaya Upland.

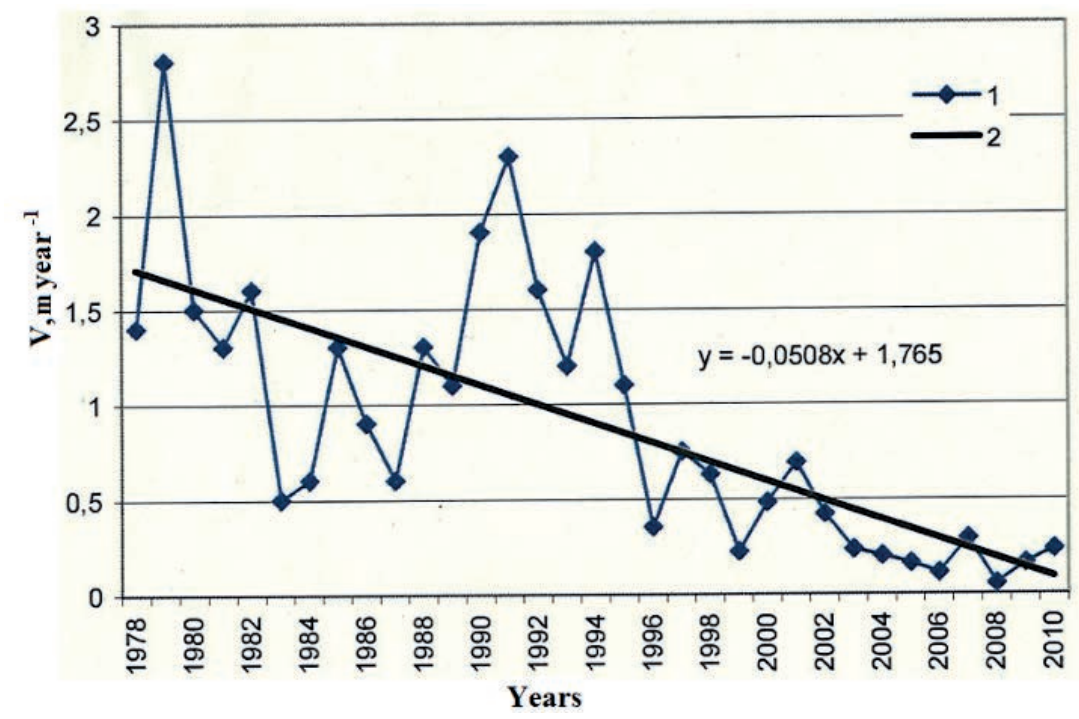

Fig. 3 Mean gully head retreat rates within the Udmurt Republic during the period 1978-2010, based on results of monitoring of 168 gully heads (Rysin \& Grigoriev, 2010). 
soil loss have significantly decreased in the Srednee Povolzhie region during the past 25 years. This observation is supported by results from the long-term monitoring of gully head retreat undertaken on 168 gully heads in the Udmurt Republic, located in the northeastern part of the region (Fig. 3). Gully head retreat is largely restricted to the snowmelt period and so it would seem very likely that surface runoff during snowmelt has become negligible in the Srednee Povolzhie region in recent decades.

\section{CONCLUSION}

Within the southern half of the Russian Plain most sediment eroded from cultivated land is deposited in a variety of sediment sinks prior to reaching the river channels. Sediment redistribution rates associated with the fluvial system of the agricultural zone of the Russian Plain have shown a significant decline over the past 25 years in response to two main factors. The first relates to the considerable decrease of surface runoff during snowmelt. This has resulted in a reduction in gross soil loss and particularly in the sediment delivery ratio within both the western and eastern parts of the Russian Plain. The second reflects the decreasing area of arable land during recent decades. This latter factor is most important in the Srednee Povolzhie region because of the greater reduction in the area of cultivated land. Although there is evidence that the frequency of high magnitude storm events has increased during the past 2-3 decades and has resulted in some increase in rates of soil loss, this has not affected the amount of sediment transported from the slopes to permanent watercourses, due to the ephemeral nature of the surface runoff.

Acknowledgements This work was funded by RFBR-RGS (project 13-05-41126) and RFBR (projects 13-05-00162 and 14-05-00503).We are very grateful to Professor Desmond Walling for his helpful input, which is greatly improved the quality of this paper.

\section{REFERENCES}

Belyaev, V.R., et al. (2008) Combining direct observations, modelling and ${ }^{137} \mathrm{Cs}$ tracer for evaluating individual event contribution to long-term sediment budgets. In: Sediment Dynamics in Changing Environments (ed. J. Schmidt et al.). IAHS Publ. 325, 114-122. Wallingford, UK, IAHS Press.

Brown, A.G., et al. (2009) From sedimentary records to sediment budgets: multiple approaches to catchment sediment flux. Geomorphology 108, 35-47.

Golosov, V.N., Belyaev, V.R. \& Markelov, M.V. (2013) Application of Chernobyl-derived ${ }^{137}$ Cs fallout for sediment redistribution studies: lessons from European Russia. Hydrological Processes 27 (6), 781-794.

Golosov, V.N., et al. (2010) Dynamics of overbank sedimentation rates on floodplains of small rivers of the Central European Russia. In: Sediment Dynamics for a Changing Future (ed. K. Banasik et al. )(Proceedings of the ICCE symposium held at The Warsaw University of Life Sciences - SGGW, Poland, 14-18 June 2010). IAHS Publ. no. 337, 129-136. Wallingford, UK, IAHS Press.

Golosov, V.N., et al. (2011) Spatial and temporal features of soil erosion in the forest-steppe zone of the East-European Plain. Eurasian Soil Sci. 7, 794-801.

Kanatieva N.P., Krasnov S.F., \& Litvin L.F. (2010). Sovremennye izmenerniya klimaticheskikh faktorov Severnogo Privolzhiya. Eroziyapochv i ruslovye processy 17, 14-27 (in Russian).

Kumani, M.V. (2003) Methods of regulation of soil erosion processes and hydrological regime of agrolandscapes of Central Chernozem zones.DSc Thesis Kursk University, Kursk (in Russian).

Litvin L.F., Kiryukhina, Z.P. \& Dobrovolskaya N.G. (2010) Transformaciya ispolzovaniya pakhotnykh zemel I ee vliyanie na erosiyu pochv. Eroziyapochv i ruslovyeprocessy, 17, 28-36 (in Russian).

Litvin, L.F. (2002) Geography of soil erosion on agricultural lands of Russia. Akademkniga, Moscow (in Russian).

Mullan, D.J. (2013) Soil erosion under the impacts of future climate change: Assessing the statistical significance of future changes and the potential on-site and off-site problems. Catena, 109, 234-246.

Nearing, M.A., Pruski, F.F. \& O’Neal, M.R. (2004) Expected climate change impacts on soil erosion rates: a review. $J$ of Soil and Water Cons. 59 (1), 43-50.

PerevedentsevYu.P., et al. (2007) Global and regional climate changes at the turn of 20th and 21th centuries. Vestnik VGU 2, 5-12 (in Russian).

Petelko A.I., Golosov V.N. \& Belyaev V.R. (2007) Experience of design of system of counter-erosion measures. In: Proc. 10th International Symposium on River Sedimentation 1,311-316. Moscow (in Russian).

Ramankutty, N. \& Foley, J. A. (1999) Estimating historical changes in land cover: North American croplands from 1850 to 1992. Global Ecology and Biogeography 8, 381-396,

Rysin, I.I. (1998) About recent trend of gully erosion in Udmurtiya. Geomorphologiya 3, 92-101 (in Russian). 
Rysin, I.I. \& Grigoryev I.I. (2010) The influence of hydrometeorological agents on the ravine growth in Udmurtia. Vestnik Udmurtskogo Universiteta, seriya Biologiya. Nauki o Zemle, 4, 137-146 (in Russian).

Schoorl, J.M., Veldkamp, A. \& Bouma, J. (2002) Modeling water and soil redistribution in adynamic landscape context. Soil Scince Society of America J. 66 (5), 1610-1619.

Shumakov, A.N. (2007) Ponds and reservoirs of Central Chernozemie as elements of erosion-slope geosystems. PhD Thesis, Kursk University, Kursk (in Russian)

Sidorchuk A.Yu. \& Golosov, V.N. (2003) Erosion and sedimentation on the Russian Plain, II: The history of erosion and sedimentation during the period of intensive agriculture. Hydrological Processes 17, 3347-3358.

Van de Wiel, M.J., et al. (2007) Embedding reach-scale fluvial dynamics within the CAESAR cellular automaton landscape evolution model. Geomorphology 90 (3-4), 283-301.

Verstraeten, G. \& Poesen, J. (2001) Factors controlling sediment yield from small intensively cultivated catchments in a temperate humid climate. Geomorphology 40 (2), 123-144.

Yermolaev O.P. (2002) Erosiya v basseinovykh geosystemakh. "Ynipress KGU", Kazan (in Russian).

Yermolaev O.P. (2013) Assessment of the suspended sediment yield in the river basins of the Russian Plain. World Applied Sciences Journal 27 (5), 626-631.

Yermolaev O. P. (2014) Erosion processes of the forest and forest-steppe zones in the eastern part of the Russian Plain. World Applied Sciences Journal 29 (3), 453-459.

Yermolaev O.P. \& Maltsev K.A. (2008) Ocenka erozionnogo riska pochvennogo pokrova v lesnykh i lesostepnykh landshaftakh Srednego Povolzhiya sredstvami GIS-technologii. Uchenye zapiski Kazanskogo Gosudarstvennogo Universiteta. Seriya estestvennye nauki 150 (4), 85-97 (in Russian).

Zolina, O., et al. (2010) Changing structure of European precipitation: longer wet periods leading to more abundant rainfalls. Geophys. Res. Lett. 37, L06704, doi:10.1029/2010GL042468. 